Article

\title{
How Toxic indeed is Oxymetazoline? Collection and Comparison of Toxicological Data of Pharmacologically Active Imidazoline Derivatives
}

\author{
Karsten Strey1,* \\ 1 Humboldtstr. 105, D-22083 Hamburg, Germany \\ * Correspondence: karsten.strey@gmx.de;
}

\begin{abstract}
Imidazoline derivatives, such as xylometazoline, naphazoline, tetryzoline, tramazoline or oxymetazoline play an important pharmacological role as nasal drops in the symptomatic treatment of rhinitis. When comparing the toxicological data of these substances, it is noticeable that Oxymetazoline has an LD 50 value which is two orders of magnitude lower than all other imidazoline derivatives. Thus, ten vials of commercially available oxymetazoline nasal drops already contain a lethal amount. An explanation for this unusually high toxicity has not yet been found.
\end{abstract}

Keywords. LD50, lethal Dose, Xylometazoline, Oxymetazoline, Imidazoline Derivatives

\section{Introduction}

Many imidazoline derivatives are basic substances for pharmaceutical products. In 1941, the pharmacological effect of imidazoline derivatives was discussed for the first time on mucous membranes [1]. In 1955, Sahyun Labs secured several synthetic routes for imidazoline derivatives, including the tetryzoline [2]. Xylometazoline was first produced by A. Hüni in 1959 [3]. This was followed by the synthesis of oxymetazoline by W. Fruhstorfer and H. Müller-Calgan in 1961 [4]. Since the decongestant effect of oxymetazoline for the nose lasted longer than with other imidazoline derivatives, an oxymetazoline product was part of the on-board pharmacy of Apollo 11 on its way to the moon in 1969 [5].

Nowadays, the imidazoline derivatives xylometazoline, tramazoline, naphazoline, tetryzoline and oxymetazoline are important drugs for nasal decongestion and as ingredients for eye drops. As $\alpha$ sympathomimetics, these substances (Figure 1.) are $\alpha_{1}$-adrenoceptor agonists. They are also used in ophthalmology to treat allergic forms of conjunctivites. It binds to the same receptors as adrenaline. In order to reduce nasal congestion during a cold, these substances have started their worldwide triumphal march in over-the-counter nasal drops. An antiviral effect has also been found in oxymetazoline. Viruses find fewer entrance gates to the nasal mucous membrane [6]. Oxymetazoline thus reduces the duration of nasal congestion by $30 \%$ [7]. Since the imidazoline derivatives also have a systemic effect, they should not be used in the case of hypertension or heart diseases. Common symptoms are also burning or dryness of the nasal mucosa. Also remarkable with these materials is the privinism. A five-day use already results in a so-called nasal drop addiction. Withdrawal from the medication leads to congestion of the mucous membrane and thus an increase in psychological strain, so that permanent damage of the mucous membrane and bark formation are the consequences of chronic use [8]. 


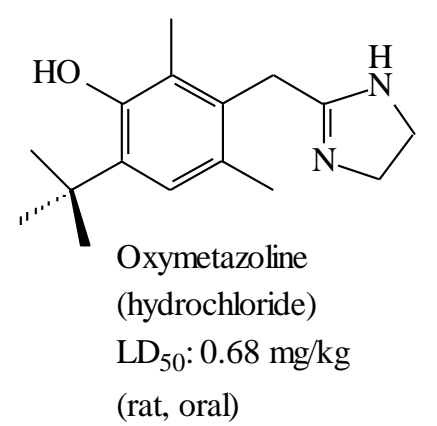<smiles>c1ccc2c(c1)CCCC2C1=NCCN1</smiles>

Tetryzoline (hydrochloride) $\mathrm{LD}_{50}: 785 \mathrm{mg} / \mathrm{kg}$ (rat, oral)<smiles>Cc1cc(C(C)(C)C)cc(C)c1CC1=NCCN1</smiles>

Xylometazoline (hydrochloride) $\mathrm{LD}_{50}: 230 \mathrm{mg} / \mathrm{kg}$ (rat, oral)<smiles>c1cc2c(c(NC3=NCCN3)c1)CCCC2</smiles>

Tramazoline (hydrochloride) $\mathrm{LD}_{50}: 190 \mathrm{mg} / \mathrm{kg}$ (rat, oral)<smiles>c1ccc2c(CC3=NCCN3)cccc2c1</smiles>

\section{Naphazoline} (hydrochloride)

$\mathrm{LD}_{50}: 1,260 \mathrm{mg} / \mathrm{kg}$ (rat, oral)<smiles>c1cc2c(c(NC3=NCCN3)c1)CCC2</smiles>

Indanazoline (hydrochloride) $\mathrm{LD}_{50}: 481 \mathrm{mg} / \mathrm{kg}$ (rat, oral)

Figure 1. Structure and $\mathrm{LD}_{50}$ values of a few imidazoline derivatives

\section{Toxicity}

Cases of poisining by imidazoline derivatives have repeatedly been observed with children [9], [10]. The tenfold $1 \mathrm{ml}$ therapeutic dose of a $0.05 \%$ oxymetazoline solution (about $0.5 \mathrm{mg}$ substance) already caused bradycardia and respiratory depression [11]. Together with alcoholic beverages tetryzoline is often misused as a so-called rape drug [12]. In 2018, there was actually a case in South Carolina, USA, where for three days a wife put large amounts of over-the-counter eye drops with tetryzoline into the drinks of her unfaithful husband. The 64-year old man died and his wife was charged [13]. All known LD50 values of the pharmacologically important imidazoline derivatives are shown in Table 1. The LD50 values of the hydrochlorides of xylometazoline, naphazoline, tetryzoline, indanazoline and tramazoline are between 190 and 1,260 mg/kg for oral administration to rats [14], [15], [16]. Surprisingly, according to Hotovy et al. [17] the LD50 value of oxymetazoline hydrochloride $(0.88 \mathrm{mg} / \mathrm{kg})$ is two order of magnitudes lower. It is unusual that at about $1 \mathrm{mg} / \mathrm{kg}$ all toxicological data assessed with rats are very similar, no matter whether the administration was subcutaneous, intravenous or oral. For all other imidazoline derivatives the values for subcutaneous and especially intravenous administration are significantly lower than for oral administration. With mice, however, the LD50 values differ significantly, as expected. At $34 \mathrm{mg} / \mathrm{kg}$ the $\mathrm{LD}_{50}$ value for oxymetazoline hydrochloride for subcutaneous administration is in the range of the comparable value of xylometazoline.

19 years after Hotovy et al. Worstmann et al. analysed the toxicological characteristics of the new indanazoline and, for comparison purposes, determined on this occasion once more the $\mathrm{LD}_{50}$ values of the hydrochlorides of tramazoline and oxymetazoline. At the same time, in comparison to Hotovy, an even lower $\mathrm{LD}_{50}$ value of $0.68 \mathrm{mg} / \mathrm{kg}$ was found in female rats [16]. Worstmann writes that oxymetazoline in female rats is over 700 times more toxic than indanazoline. The $\mathrm{LD}_{50}$ value for the intravenous administration of oxymetazoline hydrochloride to mice is, however, with $11.7 \mathrm{mg} / \mathrm{kg}$ in 
the range of xylometazoline hydrochloride $(12.5 \mathrm{mg} / \mathrm{kg})$ [14], naphazoline hydrochloride (13.2 $\mathrm{mg} / \mathrm{kg})$ [21] or tramazoline hydrochloride $(11.6 \mathrm{mg} / \mathrm{kg})$. Even with indanazoline hydrochloride, the value found of $22.3 \mathrm{mg} / \mathrm{kg}$ is only twice as high. With $22.9 \mathrm{mg} / \mathrm{kg}$, the LD50 value for the oral administration of oxymetazoline hydrochloride to the female mouse is 33 times higher than that of the female rat. Already in 1961 Hotovy et al.'s LD50 values were about 11 times higher for oral administration to mice than to rats.

Table 1. Lethal doses $\mathrm{LD}_{50} \mathrm{in} \mathrm{mg} / \mathrm{kg}$ of imidazoline derivatives

\begin{tabular}{|c|c|c|c|c|c|c|}
\hline Substance [Ref.] & $\begin{array}{c}\text { rat } \\
\text { oral }\end{array}$ & $\begin{array}{l}\text { rat } \\
\text { s.c. }\end{array}$ & $\begin{array}{l}\text { rat } \\
\text { i.v. }\end{array}$ & $\begin{array}{c}\text { mouse } \\
\text { oral }\end{array}$ & $\begin{array}{c}\text { mouse } \\
\text { s.c }\end{array}$ & $\begin{array}{c}\text { mouse } \\
\text { i.v. }\end{array}$ \\
\hline \multicolumn{7}{|l|}{ Oxymetazoline $\mathrm{HCl}$} \\
\hline Hotovy [17] & 0.88 & 1.63 & 1.07 & 10 & 34 & 5 \\
\hline \multicolumn{7}{|l|}{ Oxymetazoline $\mathrm{HCl}$} \\
\hline Worstmann [16] & 0.68 & & & 22.9 & & 11.7 \\
\hline Xylometazoline HCl [14] & 230 & 90 & & & & 12.5 \\
\hline Xylometazoline [18], [19] & & & & 180 & 63 & \\
\hline Naphazoline HCl [15], [20] & 1,260 & 385 & & 265 & 170 & 13.2 \\
\hline Naphazoline [21] & & 200 & 6 & & 170 & 16.5 \\
\hline Tetryzoline HCl [23] & 785 & 500 & 35 & 345 & 245 & 39 \\
\hline Tetryzoline [18], [22] & & & & 335 & 252 & 48.1 \\
\hline Tramazoline HCl [16] & 190 & & & 130 & & 11.6 \\
\hline Tramazoline [18] & & & & 195 & 77 & \\
\hline Indanazoline $\mathrm{HCl}$ [16] & 481 & & 16.3 & 179 & & 22.3 \\
\hline
\end{tabular}

Oxymetazoline would therefore be more toxic than mercury (II) chloride which has an $\mathrm{LD}_{50}$ value of $1 \mathrm{mg} / \mathrm{kg}$ for oral administration to rats [23]. Extrapolated to human beings, the lethal dose of xylometazoline hydrochloride would be about $16.1 \mathrm{~g}$. A $10 \mathrm{ml}$ vial of xylometazoline nasal spray contains $10 \mathrm{mg}$ of the compound. Thus, 1,610 vials would contain the lethal amount which is about the same as the content of a large bucket. On the other hand, 10 vials of oxymetazoline nasal spray ( 5 mg active substance per vial) with $50 \mathrm{mg}$ oxymetazoline hydrochloride would already contain the lethal dose, the same as the content of a champagne glass.

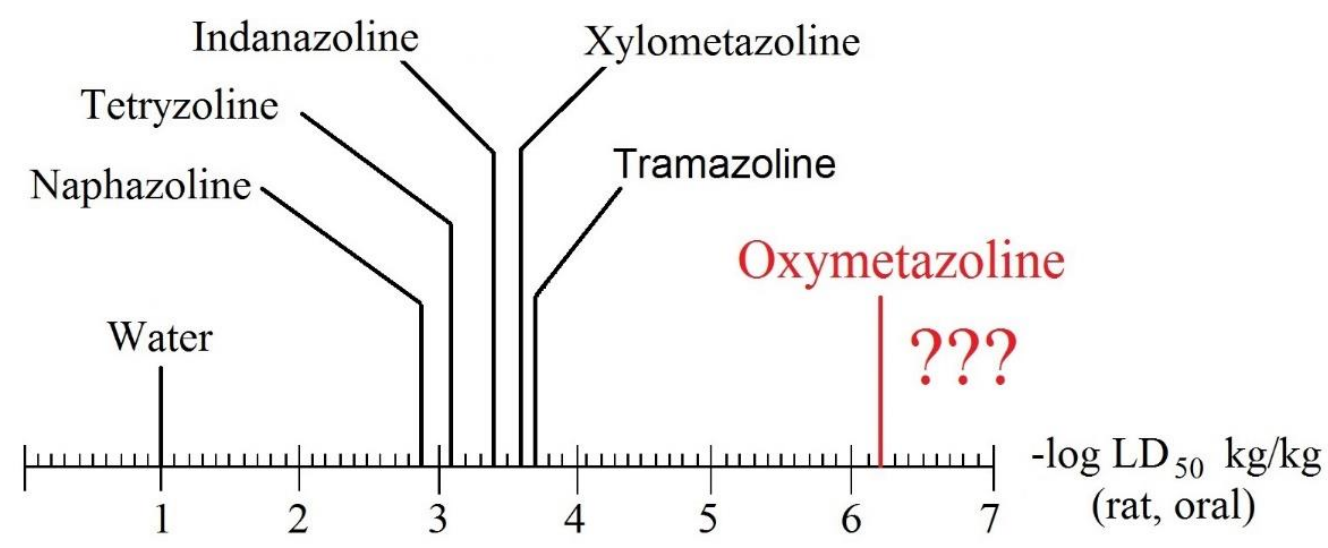

Figure 2. Poison scale [24] of some $\alpha_{1}$-adrenoceptor agonists $(\mathrm{HCl})$ and water [25] 
The big difference in toxicity between oxymetazoline and other imidazoline derivatives is shown in Figure 2. by means of the poison scale [24] that shows the negative logarithmic values of LD50. Imidazole and the alpha-blockers tolazoline and phentolamine are three other imidazoline derivatives which are chemically similar to oxymetazoline. Nevertheless, the LD50 values of 220 $\mathrm{mg} / \mathrm{kg}$ [26], $400 \mathrm{mg} / \mathrm{kg}$ [27] and 1,000 mg/kg [28] (Figure 3.) are in the range of xylometazoline or naphazoline. The high LD50 value of phentolamine is quite remarkable, since this molecule also contains a hydroxy function on a benzene ring, as in the probably over 1,000 times more toxic oxymetazoline.<smiles>c1c[nH]cn1</smiles>

Imidazole

$\mathrm{LD}_{50}: 220 \mathrm{mg} / \mathrm{kg}$

(rat, oral)<smiles>c1ccc(CC2=NCCN2)cc1</smiles>

Tolazoline (hydrochloride) $\mathrm{LD}_{50}: 400 \mathrm{mg} / \mathrm{kg}$

(mouse, oral)<smiles>Cc1ccc(N(CC2=NCCN2)c2cccc(O)c2)cc1</smiles>

Phentolamine

$\mathrm{LD}_{50}: 1,000 \mathrm{mg} / \mathrm{kg}$

(mouse, oral)

Figure 3. Structure and LD50 values of imidazole, tolazoline and phentolamine

The strikingly low LD $\mathrm{L}_{50}$ value of $0.68 \mathrm{mg} / \mathrm{kg}$ for the oral administration of oxymetazoline to the rat is reported in several data sheets [29], [30]. Goldenthal collected various toxicological data and indicated the value of $0.8 \mathrm{mg} / \mathrm{kg}$ for oxymetazoline [31]. Also the slightly higher Hotovy value of $0.88 \mathrm{mg} / \mathrm{kg}$ was found [32]. The higher values for mice remain unconsidered.

\section{Conclusion}

The comparison with the available toxicological data of other imidazoline derivatives, however, contests the generally accepted LD 50 value of $0.68 \mathrm{mg} / \mathrm{kg}$ for oxymetazoline hydrochloride. The chemical functions and structure of oxymetazoline do not obviously explain the strikingly high toxicity with rats. Therefore, new toxicological studies should review the data of Hotovy et al. and Worstmann et al. of 1980, correct them, if necessary, or find an explanation for the high toxicity.

Acknowledgments: The author thanks Astrid Menzel and Morimichi Hasegawa for translations.

Conflicts of Interest: The author declares there is no conflict of interest.

\section{References}

1. Meier, R; Müller, R. Pharmakologische Untersuchungen über eine neuartige Substanz mit anämisierender Wirkung auf den Schleimhäuten. Schweiz. Med. Wschr. 1941, 17, 554-556.

2. Sahyun, M. US-Patent 2,890,984, Pharmaceutical composition containing 2-(1,2,3,4-tetrahydro-1naphthyl)imidazoline. 1955.

3. Hüni, A. Ger. Patent 1,049,387, Verfahren zur Herstellung einer neuen stickstoffhaltigen Verbindung. 1959.

4. Fruhstorfer, A; Mueller-Calgan, H. Ger. Patent 1,117,588, Verfahren zur Herstellung eines neuen Imidazolinderivates. 1961.

5. Saiger, C. Krank im All - Weltraumapotheke für alle Fälle. Pharmazeutische Zeitung 2009, 28, 2588-2595. 
6. Koelsch, S; Tschaikin, M.; Sacher, F. Anti-Rhinovirus-specific Activity of the Alpha-sympathomimetic Oxymetazoline. Arzneimittel-Forsch. 2007, 57, 475-482. https://doi.org/10.1055/s-0031-1296635

7. Reinecke, S.; Tschaikin, M. Untersuchung der Wirksamkeit von Oxymetazolin auf die Schnupfendauer. MMW-Fortsch. Medizin. 2005, 147, 113-118.

8. Graf, P. Rhinitis Medicamentosa - a Review of Causes and Treatment. Treat. Respir. Med. 2005, 4, 21-29. https://doi.org/10.2165/00151829-200504010-00003

9. Mahieu, L.M.; Rooman, R.P.; Goosens, E. Imidazoline intoxication in children. Eur. J. Pediatr. 1993, 152, 944946. https://doi.org/10.1007/BF01957538

10. Neubert, A. Oxymetazolin und Xylometazolin - Gefahr für Säuglinge und Kleinkinder. Pharmazeutische Zeitung 2013, 34. www.pharmazeutische-zeitung.de/index.php?id=48320

11. Nordt, S.P.; Vivero, L.E.; Cantrell, F.L. Not Just a Drop in the Bucket - Inversion of Oxymetazoline Nasal Decongestant Container Increases Potential for Severe Pediatric Poisoning. J. Pediatr. 2016, 168, $240-241$. https://doi.org/10.1016/j.jpeds.2015.09.067

12. Stillwell, M.E.; Saady, J.J. Use of tetrahydrozoline for chemical submission. Forensic Sci. Int. 2012, 211, 12-16. https://doi.org/10.1016/j.forsciint.2012.04.004

13. Betuel, E. How eyedrops were used as a poison in South Carolina murder case. Inverse, September 4th. 2018. inverse.com/article/48622-eyedrops-used-poison-south-carolina-murder

14. Ueda, K.; Nishimura, M.; Maebashi, H.; Tanabe, M.; Konishi, T.; Yamamura, T.; Morimoto, K. Acute, subacute and chronicle toxicity tests of Xylometazoline Hydrochloride. Kiso to Rinsho. Clinical Report 1971, 55-85.

15. Kleemann, A.; Engel, J.; Kutscher, B.; Reichert, D. Pharmaceutical Substances: Syntheses, Patents, Applications of the most relevant APIs. 5th ed.; Thieme Verlag, Stuttgart, pp. 1358, 2009.

16. Worstmann, W.; Leuschner, F.; Neumann, W.; Kretzschmar, R. Toxicity studies on N-(2-imidazolinew-2yl)N-(4-indanyl)amine monohydrochloride (indanazoline), a new rhinologic drug. Arzneimittel-Forsch. 1980, 30, 1760-1771.

17. Hotovy, R.; Enenkel H.J.; Gillissen, J.; Jahn, U.; Kieser, H.; Kraft, H.G.; Mueller-Calgan, H.; Sommer, S.; Wahlig, H. On the pharmacology of 2-(4-tert-butyl-2,6-dimethyl-3-hydroxybenzyl)-2-imidazolinumchloride. Arzneimittel-Forsch. 1961, 11, 1016-1022.

18. Engelhorn, R.; Klupp, H. Pharmakologische Wirkung von 2-(1,2,3,4-Tetrahydro-1-naphthylamino)-2imidazolin-hydrochlorid. Arzneimittel-Forsch. 1962, 12, 971-975.

19. Picciòla, G.; Carissimi, M.; Ravenna, F.; Gentili, P.; Carenini, G. Cyclohexylphenoxy amidoximes and imidazolines with antidepressive and alpha-adrenergic activity. Arzneimittel-Forsch. 1979, 29, 729-738.

20. Gylfe, J.; Hendricks, R.; Ochs, S.; Williams, H.L. Hypothermic agents: I.: 4-amyl N-benzohydrylpyridinium bromide (B-45) and alpha naphthylmetyhl imidazoline (privine). Fed. Proc. 1950, 9, 280-281.

21. Hutcheon, D.E.; P 'An, S.Y.; Gardocki, J.F.; Jaeger, D.A. The sympathomimetic and other pharmacological properties of DL 2-(1,2,3,4-tetrahydro-1-naphthyl)-imidazoline (tetrahydrozoline). J. Pharmacol. Exp. Ther. 1955, 113, 341-352.

22. Sunshine, I.: CRC Handbook of analytical toxicology. Chemical Rubber Company, Cleveland, Ohio, 1969.

23. Worthing, C. Pesticide Manual. 9th Ed. Farnham, Surrey, British Crop Protection Council, p. 550.1991.

24. Strey, K. Die Gifte-Skala. Chem. Unserer Zeit 2019, 53, 386-399. https://doi.org/10.1002/ciuz.201900828

25. Eagle, E.; Poling, C.E. The oral toxicity and pathology of polyoxyethylene derivates in rats and hamsters. J. Food Sci. 1956, 21, 348-361. https://doi.org/10.1111/j.1365-2621.1956.tb16931.x|

The LD50 of water is above $0.09 \mathrm{~kg} / \mathrm{kg}$. For this, the most non-toxic substance obtains the notable value of 1 on the poison scale.

26. Kostka, G.; Palut, D. Toxicity of aldehydes used as disinfectants. Przegl. Epidemiol. 1973, 67, 295-303.

27. Carron, C.; Jullien, A. Bucher, B. Synthesis and pharmacological properties of a series of 2-piperidino alkanol derivatives. Arzneimittel-Forsch. 1971, 21, 1992-1998.

28. Harvengt, C.; Jeanjean, M. Acute toxicity of phentolamine in rabbits. Arch. Int. Pharmacodyn. Ther. 1968, 174, 243-245.

29. sciencelab.com/msds.php?msdsld=9926366

30. abcam.com/ps/Products/120/ab120712/Msds/ab120712_CLP1_EN.pdf

31. Goldenthal, E.L. A compilation of LD50 values in newborn and adult animals. Toxicol. Appl. Pharm. 1971, 18, 185-207. https://doi.org/10.1016/0041-008X(71)90328-0

32. toxnet.nim.nih.gov/cgi-bin/sis/search/a?dbs+hsdb:@term+@DOCNO+3143. 